\title{
Simulasi Sistem Kerja Bioseptic Tank Berbasis Dua Dimensi
}

\author{
Narti $^{1}$, Sriyadi ${ }^{2}$, Darul Annas Septihan ${ }^{3}$, Mahmud Syarif ${ }^{4}$ \\ ${ }^{1}$ STMIK Nusa Mandiri \\ e-mail: narti.nrx@nusamandiri.ac.id \\ ${ }^{2}$ Universitas Bina Sarana Informatika \\ e-mail: sriyadi.sry@bsi.ac.id \\ ${ }^{3}$ STMIK Nusa Mandiri \\ e-mail: darulannas7@gmail.com \\ ${ }^{4}$ Universitas Bina Sarana Informatika \\ e-mail: mahmud.may@bsi.ac.id
}

Cara Sitasi: Narti, N., Sriyadi, S., Septihan, D. A., \& Syarif, M. (2019). SIMULASI SISTEM KERJA BIOSEPTIC TANK BERBASIS DUA DIMENSI. Paradigma - Jurnal Komputer dan Informatika, 21(2), 253260. doi:10.31294/p.v21i2.5716

\begin{abstract}
In the business environment, especially in the business of selling a product, it definitely requires a user-friendly tutorial or instructions for using the product, the tutorial can be in the form of flow pictures or in the form of interactive two-dimensional (2D) or three-dimensional (3D) animation. The tutorial can function as a tool for introducing a product for buyers and potential buyers so that buyers' interest will increase and add buyer knowledge about the product. Now the author is encouraged to make a teaching aid using twodimensional interactive animation that is user-friendly and interesting for PT. Global Core Fibertech. By using two-dimensional sketches to explain the product and use the video directly displayed the bioseptic tank's working system can allow customers to be interested in the product and not close the possibility that other competitors will gradually follow the animation method. With the design of the two-dimensional interactive animation, it is expected to increase the effectiveness, quality and intensity of its sales. With the technology used, the tools for making Adobe Flash CS6 as an application for making interactive animations, Adobe Photoshop CC as an application for making Bioseptic Tank and Actionscript sketches to move the animation process and application development methods used are Waterfall.
\end{abstract}

Keywords: Bioseptic Tank, Interactive Animation, 2D

\section{PENDAHULUAN}

Kemajuan dunia teknologi sangat drastis sehingga menuntut kita untuk memperoleh informasi secara cepat dan mudah, yang sekarang ini dirasakan semakin menjadi kebutuhan pokok yang mendesak. Dengan begitu akan mempermudah seseorang untuk mengakses informasi. Suatu bentuk informasi yang mudah untuk disajikan yaitu dalam bentuk animasi interaktif.

PT. Global Inti Fibertech adalah salah satu perusahaan yang bergerak di bidang penjualan produk fiber seperti, Bioseptic Tank, Instalasi Pengolahan Air Limbah (IPAL), Sewage Treatment Plant (STP), toilet portable dan lain-lain. Kendala yang dihadapi oleh PT. Global Inti Fibertech adalah bagaimana menjelaskan sistem kerja Bisoseptic Tank khususnya dan selama ini hanya menggunakan media gambar manual 2D dan video untuk melihat sistem yang terdapat pada produk secara langsung. Selama ini PT. Global Inti Fibertech belum memanfaatkan teknologi informasi seperti animasi interaktif 2D sebagai alat peraga untuk pengenalan sistem kerja Bisoseptic Tank sehingga perusahaan mengalami kesulitan dalam menjelaskan sistem kerja tersebut. Dengan cara yang masih serba manual tentu tidak efektif dan efisien sehingga sangat menghambat perkembangan perusahaan.

Dalam hal ini PT. Global Inti Fibertech perlu memanfaatkan kemajuan dibidang teknologi informasi sebagai alat peraga untuk pengenalan sistem kerja Bisoseptic Tank. Dengan memanfaatkan teknologi informasi seperti animasi interaktif sebagai alat peraga maka akan dapat mempermudah proses penjelasan. PT. Global Inti Fibertech membutuhkan sebuah aplikasi animasi interaktif 2D yang bisa menunjang proses penjelasan dan sebagai alat peraga bisoseptic tank. Dengan adanya aplikasi animasi interaktif 2D ini akan mempermudah para pembeli atau calon pembeli untuk memahami sistem kerja Bioseptic Tank hanya 
dengan melihat animasi interaktif dan membuat minat serta ketertarikan meningkat.

Menurut Lisana, "Media pembelajaran yang umum untuk mempelajari cara berkendara yang baik adalah buku. Akan tetapi pembelajaran melalui buku ini mempunyai kelemahan yaitu membosankan karena tidak ada unsur interaksi. Selain itu cukup sulit mengukur tingkat pemahaman pemakai terhadap materi yang dipelajari” (Mulyani \& Armanda, 2015).

Menurut Junaidi, "Dalam proses pembelajaran guru dapat bervariasi menggunakan animasi interaktif agar siswa lebih aktif dan mudah memahami materi yang di sampaikan oleh guru. Selain itu dengan menggunakan Animasi Interaktif siswa tidak merasa monoton karena pembelajaran hanya menggunakan buku saja. Suasana belajar mengajar pun lebih menyenangkan" (Saryoko \& Susilowati, 2018).

Menurut Noviyanto, "Informasi berbentuk multimedia lebih menarik dibandingkan dengan informasi bentuk teks, dengan demikian dibutuhkan perangkat lunak penunjang animasi seperti flash. Untuk menciptakan sumber daya manusia yang berkualitas yang dapat mengikuti perkembangan kemajuan teknologi pembelajaran" (Akmaludin, 2013).

Pada kesempatan ini, penulis memanfaatkan fasilitas aplikasi Adobe Flash CS6 untuk merancang dan membuat sebuah animasi interaktif 2D yang bisa memberikan informasi mengenai sistem kerja Bioseptic Tank pada PT. Global Inti Fibertech yang dapat meningkatkan efektifitas dan efisiensi perusahaan sehingga tidak menghambat perkembangan perusahaan.

\section{METODOLOGI PENELITIAN}

Metode Penelitian dalam rangka pengumpulan data yang diperlukan dalam penelitian ini, penulis menggunakan beberapa metode diantaranya :

A. Metode Pengumpulan Data

Teknik pengumpulan data yang penulis gunakan dalam penelitian ini adalah:

1) Pengamatan Langsung (Observation)

Dalam metode ini penulis melakukan pengamatan objek penelitian secara langsung terhadap proses penjualan untuk memperkenalkan produk Bioseptic Tank PT. Global Inti Fibertech kepada pembeli atau calon pembeli.

2) Wawancara

Wawancara kepada pihak-pihak yang terkait yang mengalami kendala untuk memberikan informasi mengenai produk Bioseptic Tank PT. Global Inti Fibertech kepada pembeli atau calon pembeli.

3) Studi Pustaka (Library Research)

Penulis mempelajari dan membaca buku-buku sebagai bahan acuan penelitian ini dengan mengembangkan pengetahuan penulis.

\section{B. Model Pengembangan Sistem}

Model yang di gunakan dalam pembuatan perangkat lunak ini menggunakan model air terjun (waterfall) yang sering di sebut juga model sekuensial linier (sequential linear) atau alur hidup klasik. Model ini (Sukamto dan Shalahuddin, 2015:28) terbagi menjadi 5 tahapan, yaitu :

1) Analisis Kebutuhan Perangkat Lunak

Pada tahap ini penulis menganalisa kebutuhankebutuhan apa saja yang dibutuhkan dalam pembuatan aplikasi animasi interaktif 2D sistem kerja Bioseptic Tank PT. Global Inti Fibertech. Kebutuhan nya berupa dokumen masukan sistem pengenalan sebelumnya, yaitu foto, video dan brosur Bioseptic Tank, serta dokumen keluaran sistem pengenalan sebelumnya, yaitu gambar teknik sistem Bioseptic Tank

2) Desain

Setelah menganalisa kebutuhan, penulis membuat desain dengan merancang Karakter Software, perancangan Story Board untuk menggambarkan jalan nya alur cerita animasi, User Interface untuk merancang tampilan tatap muka animasi, dan State Transition Diagram untuk menggambarkan bagaimana suatu proses animasi dihubungkan.

3) Pembuatan Kode Program

Pada tahap ini penulis membuat aplikasi menggunakan kode pemrograman Action Script yang berfungsi untuk menggerakan animasi secara interaktif. Aplikasi yang digunakan untuk membuat kode pemrograman yaitu adobe flash cs6.

4) Pengujian

Pada tahap ini penulis melakukan percobaan menggunakan Black Box testing dari aplikasi animasi interaktif 2D yang sudah dibuat, apakah setiap tools berjalan dengan baik. Dan apakah aplikasi animasi interaktif 2D sudah sesuai dengan keinginan pemakai. Apabila masih ada kesalahan akan dilakukan perbaikan. Pada dasarnya Black Box Testing adalah metode pengujian perangkat lunak yang berfokus pada fungsi, khususnya pada input dan output program yang dibuat. Dan juga menggunakan White Box testing untuk pengujian yang didasarkan pada pengecekan terhadap detail perancangan, menggunakan struktur kontrol dari desain program secara prosedur.

5) Pendukung (support) atau Pemeliharaan (maintenance)

Pada tahap ini sistem yang telah dibuat memerlukan hardware maupun software pendukung lainnya. Software yang diperlukan yaitu adobe flash cs6 untuk pembuatan animasi interaktif yang didukung dengan bahasa Action Script untuk menggerakan animasi secara interaktif serta adobe photoshop cc untuk pembuatan gambar pendukung dan juga sistem operasi windows 10 .

Selain itu jika ada sistem Bioseptic Tank yang di perbarui maka diperbarui juga lah aplikasi ini. Dan untuk hardware yang dipakai, termasuk hardware yang harus mempunyai spesifikasi yang dapat menunjang tiap proses pembuatan animasi interaktif 2D, disini penulis menggunakan laptop dengan dibekali Prosesor Intel Core i5, VGA Nvidia, dan 
8GB RAM . Jika ada kerusakan maka akan segera dilakukan perbaikan atau tindakan.

\section{HASIL DAN PEMBAHASAN}

PT. Global Inti Fibertech Tangerang adalah perusahaan yang bergerak di bidang Manufacture dan penjualan produk berbahan Fiberglass (Fiberglass Reinforce Plastic Product) yang sebagian besar pelanggan kami berhubungan dengan proyek-proyek Pembangunan, Perumahan, Apartemen, Mall, Rumah Sakit, Sekolah, Universitas, Restoran, Departemen Pemerintahan, Kontraktor, Developer, dan Waste Water Treatment. Sejak berdiri dan disahkannya perusahaan pada tanggal 18 April 2013 dengan nomor NPWP 31.709.648.5-418.000. PT. Global Inti Fibertech yang berdomisili di Tangerang mempunyai Visi dan Misi yang telah dibangun bersama. Setiap langkah PT. Global Inti Fibertech akan selalu menerapkan nilai-nilai yang telah dikembangkan bersama.

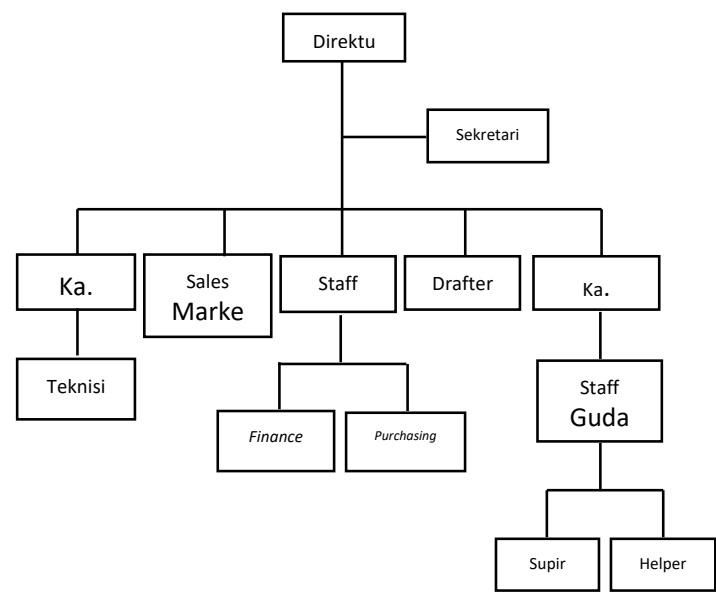

Sumber: PT. Global Inti Fibertech Tangerang (2018)

Gambar 1. Struktur Organisasi

\subsection{Karakteristik Software}

1. Format

File ditulis dengan Format file .swf dan .exe sehingga user bisa langsung menjalankan tanpa perlu install Adobe Flash Professional CS6.

2. Rules

Rules adalah aturan atau pola yang harus diikuti untuk dapat memahami animasi interaktif Bioseptic Tank tersebut. Adapun pola nya adalah, pengguna membuka aplikasi animasi interaktif Bioseptic Tank lalu muncul halaman utama, setelah itu klik tombol start, lalu akan tampil menu utama. Di menu utama pengguna dapat memilih Bioseptic Tank tipe apa yang ingin di pahami sistem nya dengan klik tombol tipe nya yang selanjutkan akan muncul tombol-tombol untuk menjalankan proses sistem Bioseptic Tank.

3. Policy

Dalam kebijakan ini dibuat perancangan animasi interaktif pengenalan Bioseptic Tank yang berisikan tipe-tipe Bioseptic Tank. Dengan menampilkan main menu pilihan menu Tipe RC, Tipe BCR, Tipe BCX, Tipe BFS, Tipe BK.

4. Scenario

Dalam program aplikasi ini terdapat 5 pilihan menu yang dapat dipilih diantaranya :

a. Tombol Tipe RC yaitu user dapat mempelajari isi materi tentang Tipe RC.

b. Tombol Tipe BCR yaitu user dapat mempelajari Tipe BCR..

c. Tombol Tipe BCX yaitu user mempelajari Tipe BCX..

d. Tombol Tipe BFS yaitu user mempelajari Tipe BFS.

e. Tombol Tipe BK yaitu user dapat mempelajari Tipe BK.

5. Events / Challenge

Di setiap pilihan tombol terdapat frame-frame aksi pilihan menu.

6. Roles

User harus dapat menjawab dari setiap pertanyaan-pertanyaab dengan dengan benar untuk mengetahui pemahaman user dengan baik.

7. Decisions

Dimana pengguna dapat menentukan pilihan tombol pada menu utama yang manakah yang akan pengguna buka terlebih dahulu.

8. Indicators

Indikasi penentuan keberhasilan dalam pemahaman animasi ini tentang bio septic tank adalah adalah dapat menjawab semua pertanyaan dengan benar.

9. Symbols

Sebagai petunjuk ke state berikutnya atau ke state sebelumnya digunakan tanda panah selanjutnya atau kembali. Selain itu juga terdapat tombol-tombol yang berupa gambar dan text untuk proses belajar user.

\subsection{Perancangan Storyboard}

Perancangan Story board berisi terjemahan berupa gambar cerita naskah dari aplikasi yang dibuat dan akan disampaikan dengan menggunakan tulisan dan gambar. Berikut menceritakan alur dari aplikasi tersebut.

a. Storyboard Opening

Berikut ini adalah gambaran dari storyboard opening yaitu:

Tabel 1. Story Board Opening

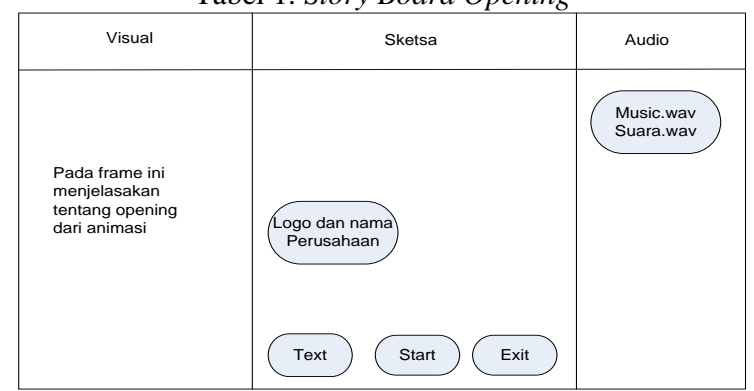


b. Storyboard Halaman Awal

Berikut ini adalah gambaran dari storyboard Halaman awal yaitu:

Tabel 2. Story Board Halaman awal

\begin{tabular}{|c|c|c|c|}
\hline Visual & & Sketsa & Audio \\
\hline $\begin{array}{l}\text { Menjelaskan tentang } \\
\text { menu utama yang } \\
\text { terdapat pada animasi }\end{array}$ & & & \\
\hline & & & \\
\hline & & & \\
\hline & & & \\
\hline
\end{tabular}

c. Storyboard RC

Berikut ini adalah gambaran dari storyboard $R C$ yaitu:

Tabel 3. Story Board RC

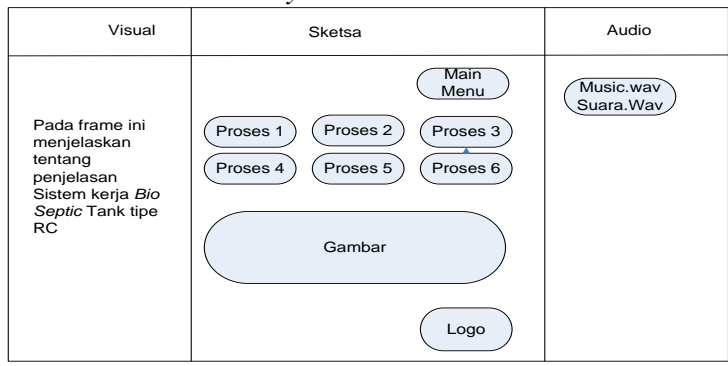

d. Story board BCR

Berikut ini adalah gambaran dari storyboard $B C R$ yaitu:

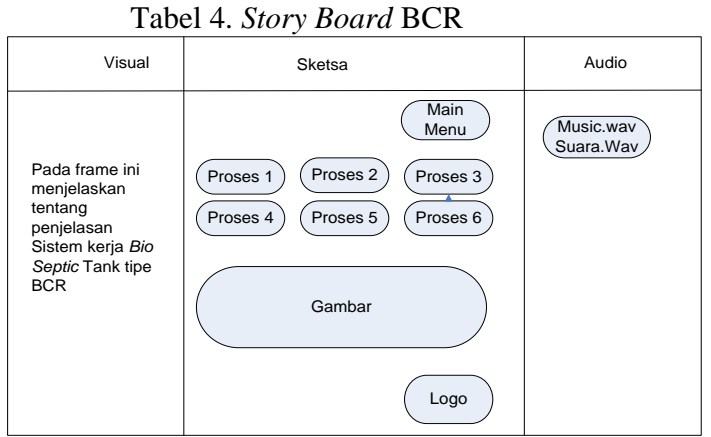

\section{e. Storyboard BCX}

Berikut ini adalah gambaran dari storyboard $B C X$ yaitu:

Tabel 5. Story Board BCX

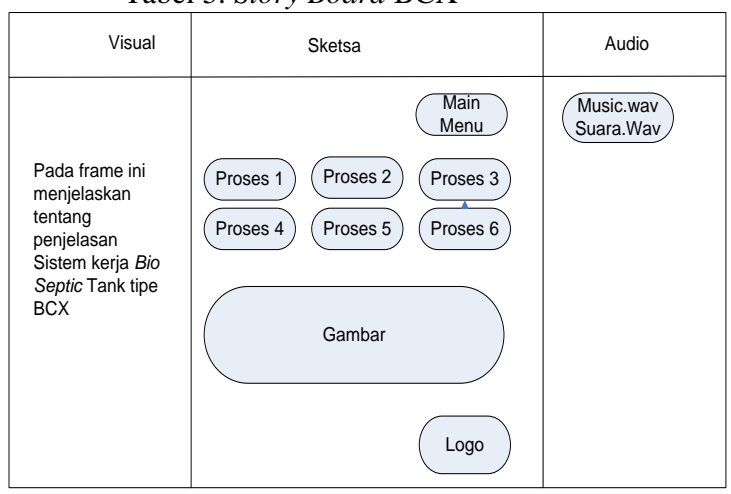

\section{f. Storyboard BFS}

Berikut ini adalah gambaran dari storyboard BFS yaitu:

\begin{tabular}{|l|l|l|}
\hline \multicolumn{1}{|c|}{ Tabel 6. Story Board BFS } \\
\hline \multicolumn{1}{|c|}{ Visual } & \multicolumn{1}{|c|}{ Audio } \\
\hline $\begin{array}{l}\text { Pada frame ini } \\
\text { menjelaskan } \\
\text { tentang } \\
\text { penjelasan tipe } \\
\text { BFS }\end{array}$ & & \\
\hline
\end{tabular}

\section{g. Storyboard BK}

Berikut ini adalah gambaran dari storyboard $B K$ yaitu:

\begin{tabular}{|l|l|r|}
\hline \multicolumn{1}{|c|}{ Tabel 7.Story Board BK } & Audio \\
\hline \multicolumn{1}{|c|}{ Visual } & & Sketsa \\
\hline
\end{tabular}

h. Storyboard Tentang Kami

Berikut adalah storyboard tentang kami: Tabel 8. Story Board Tentang Kami

\begin{tabular}{|l|l|l|}
\hline \multicolumn{1}{|c|}{ Visual } & \multicolumn{2}{|c|}{ Sketsa } \\
\hline $\begin{array}{l}\text { Pada frame ini } \\
\text { menjelaskan } \\
\text { tentang } \\
\text { Perusahaan PT } \\
\text { Global Inti } \\
\text { Fibertech }\end{array}$ & Kembali \\
\hline Lext
\end{tabular}

\subsection{User Interface}

Pada pembuatan aplikasi ini bersifat pembelajaran, dibuat tidak terlalu berlebihan, dan dibuat semenarik mungkin sehingga mampu menyesuaikan dari fungsi dari animasi ini. Pada beberapa halaman dan tombolnya diberikan efek suara, sehingga mampu menambah efek menarik dari aplikasi ini. Animasi ini juga mudah digunakan (user friendly), tombol (button) penghubung antara satu scane dengan scane lainnya yang mudah dipahami, sehingga tidak mempersulit pengguna untuk menggunakan aplikasi tersebut. Tampilan user interface dari aplikasi ini antara lain sebagai berikut. 


\section{a. Halaman Opening}

Halaman Opening ini berisikan tentang judul program animasi yang sedang dimainkan, animasi daun yang jatuh dari atas ke bawah dari aplikasi tersebut.

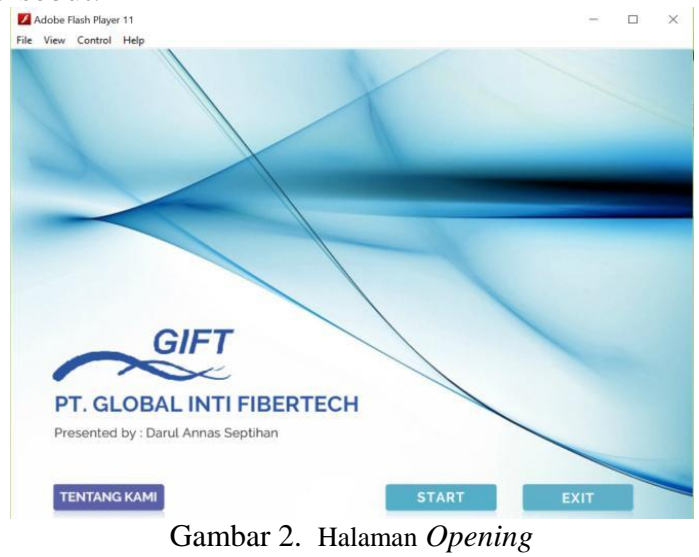

b. Halaman Menu Utama

Halaman Menu Utama yang berisikan tentang menumenu yang terdapat pada animasi, yaitu:

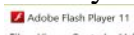

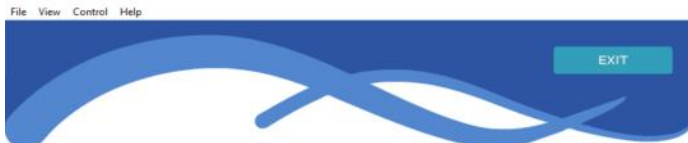

SISTEM

KERJA

BIO SEPTIC

TANK
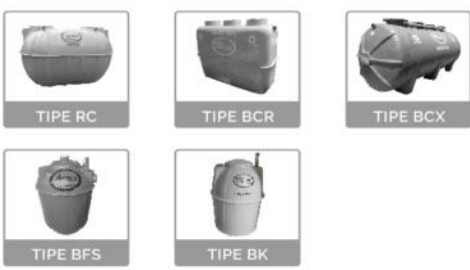

Gambar 3. Halaman Menu Utama

c. Halaman Menu RC

Halaman ini berisi tentang materi RC, yaitu:

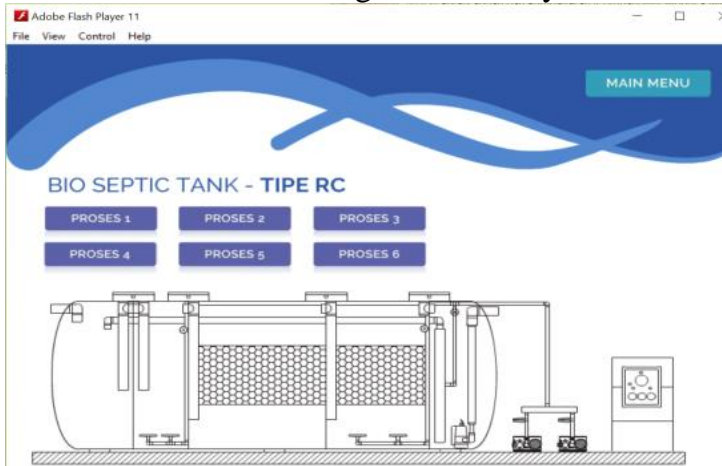

Gambar 4. Halaman Menu tipe RC

d. Halaman Menu BCR

Halaman ini berisi tentang materi BCR, yaitu:

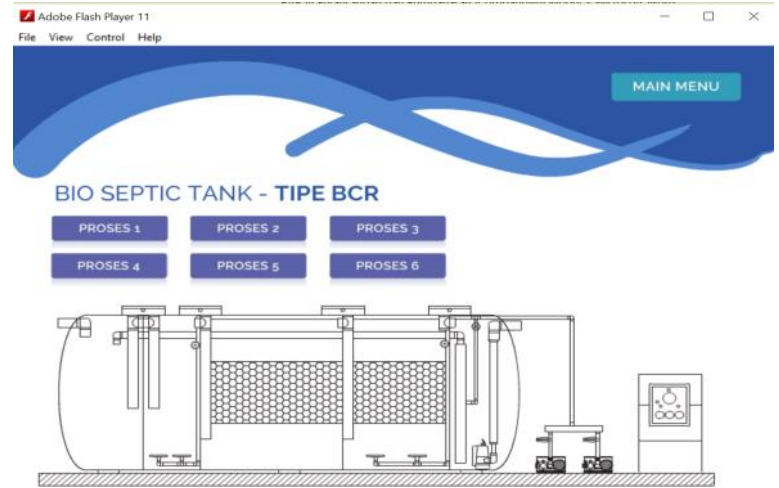

Gambar 5. Halaman Menu tipe BCR

e. Halaman Menu BCX

Halaman ini berisi tentang materi BCX, yaitu:

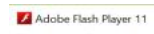

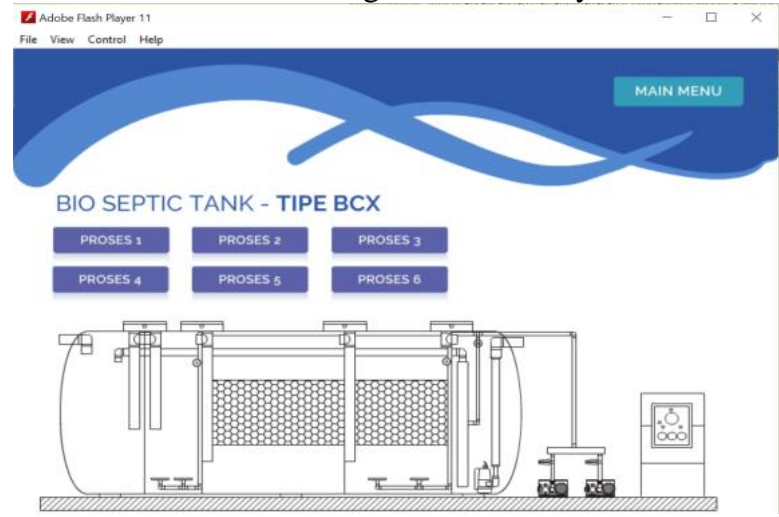

Gambar 6. Halama Menu tipe BCX

f. Halaman Menu BFS

Halaman ini berisi tentang materi BFS, yaitu: Dadobe Flash Player 11

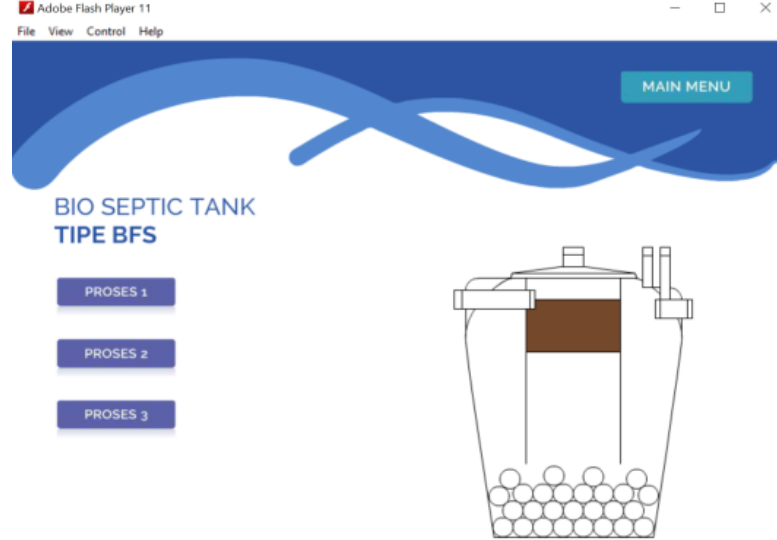

Gambar 7. Halaman Menu tipe BFS

g. Halaman Menu BK

Halaman ini berisi tentang materi BK, yaitu: 


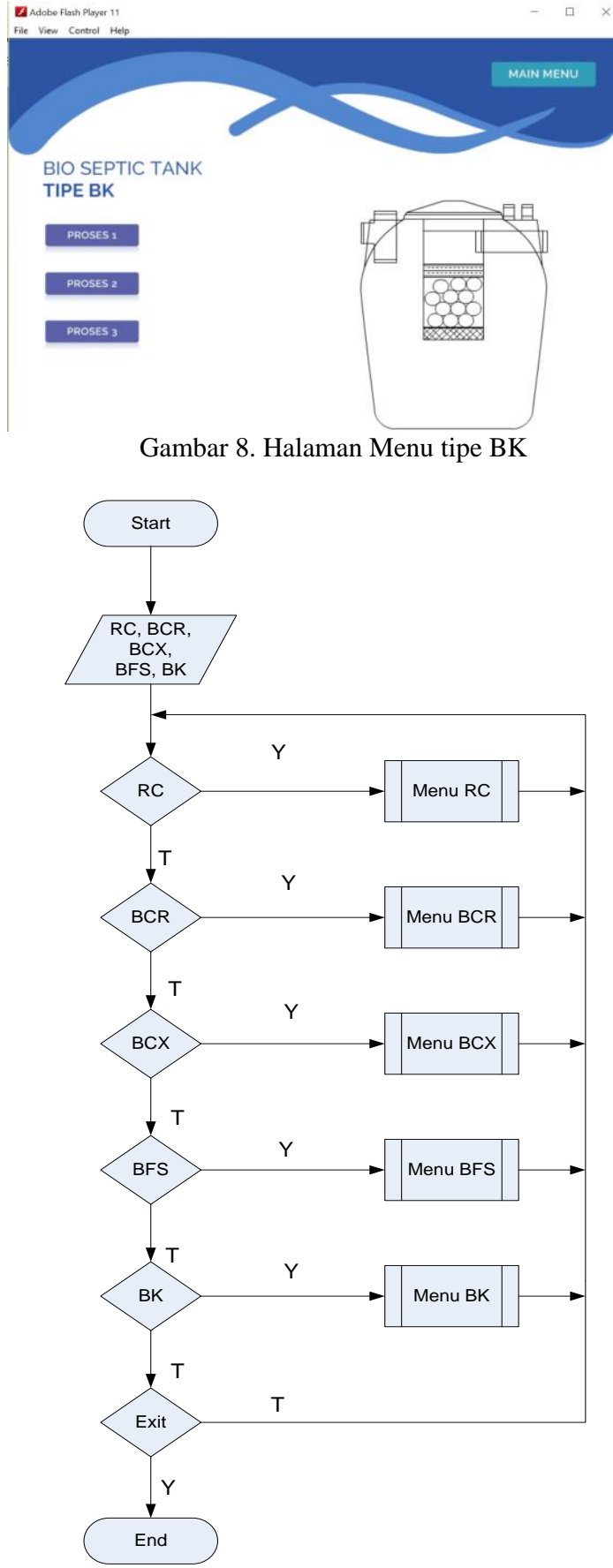

Gambar 9. Bagan Alir Halaman Scane Transition Diagram Menu Utama

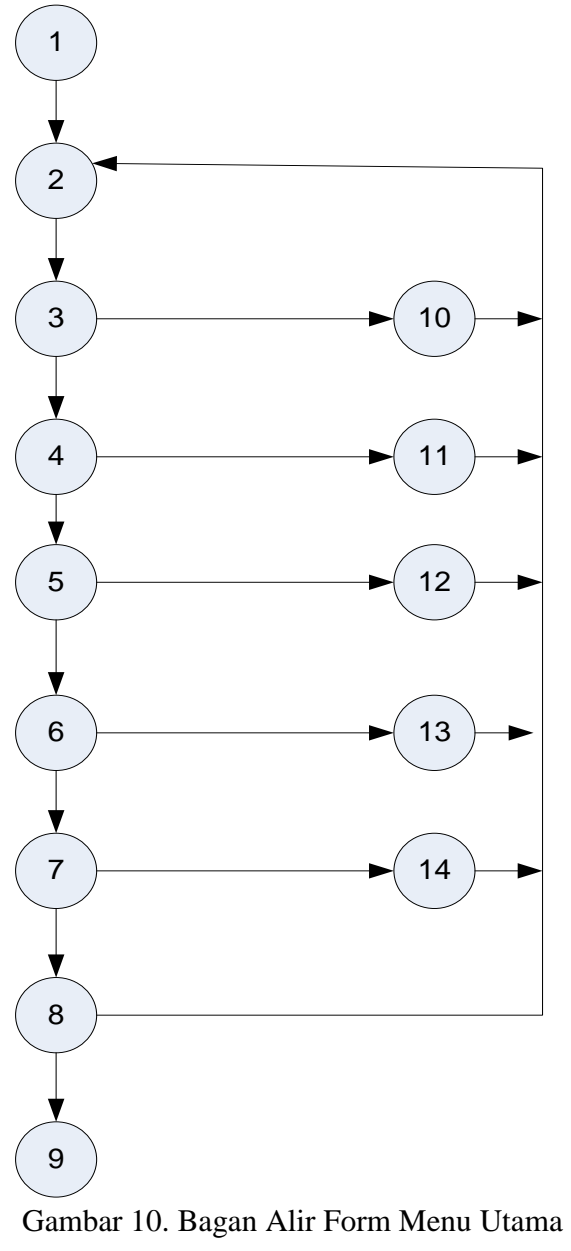

Kompleksitas siklomatis (pengukuran kualitatif terhadap kompleksitas logis suatu program) dari grafik alir dapat diperoleh dengan perhitungan

$$
\mathrm{V}_{(\mathrm{G})}=\mathrm{E}-\mathrm{N}+2
$$

Dimana :

$\mathrm{E}=$ Jumlah $e$ dge grafik alir yang ditandakan dengan gambar panah

$\mathrm{N}=$ Jumlah simpul grafik alir yang di tandakan dengan gambar lingkaran

Sehingga kompleksitas siklomatisnya

$\mathrm{V}(\mathrm{G})=19-14+2=7$

Basis set dihasilkan dari jalur independent secara linier adalah jalur sebagai berikut:

$1-2-3-4-5-6-7-8-9$

$1-2-3-4-5-6-7-8$

$1-2-3-4-5-6-7-14$

$1-2-3-4-5-6-13$

$1-2-3-4-5-12$

$1-2-3-4-11$

$1-2-3-10$

Ketika aplikasi dijalankan, maka terlihat salah satu set yang dihasilkan adalah 1-2-3-4-5-6-7-8-9 dan terlihat bahwa simpul telah dieksekusi satu kali. Berdasarkan pengamatan ketentuan tersebut dari 
kelayakan software. System ini telah memenuhi syarat. Adapun untuk alur jalan sama setiap yang dijalankan, hanya berupa jenis materi yang disediakan.

\section{KESIMPULAN}

PT. Global Inti Fibertech dalam menjalankan pengenalan sistem kerja Bisoseptic Tank masih menggunakan manual sketsa $2 \mathrm{D}$ dan video untuk melihat sistem yang terdapat pada produk secara langsung. Dengan adanya aplikasi animasi interaktif 2D PT. Global Inti Fibertech ini akan mempermudah para pembeli atau calon pembeli untuk memahami sistem kerja Bioseptic Tank hanya dengan melihat animasi dan membuat daya minat pembeli serta ketertarikan pembeli atau calon pembeli meningkat.

\section{REFERENSI}

Akmaludin. (2013). Vol . IX No . 2 September 2013 INFORMASI MENGGUNAKAN MATURITY LEVEL Pilar Nusa Mandiri Vol . IX No . 2 September 2013. Jurnal Pila, IX(2), 123-130.

Chandra.2011. 7 Jam Belajar Interaktif, Flash CS5 untuk Orang Awam. Palembang:Maxikom.

Christian, A., Ariani, F., \& Rizal, K. (2014). Animasi Interaktif Peningkatan Kemampuan Mengenal Huruf Untuk Anak Usia Dini. Simposium Nasional Ilmu Pengetahuan Dan Teknologi (SIMNASIPTEK), (ISBN:978-60261268-2-5), 179-183.

Endika, R., \& Harafani, H. (2014). Pembelajaran Proses Pembuatan Madu Berbasis RPGAdventure pada Game Petualangan Titan Pembelajaran merupakan suatu kegiatan yang melibatkan seseorang dalam upaya memperoleh dengan memanfaatkan berbagai sumber untuk belajar . bantu untuk menjelaskan sebagi. Jurnal Techno Nusa Mandiri, XI(2), 158-168.

Kadir, Abudl.2015. From Zero to a Pro, Pemrograman C.Yohyakarta:Andi.

Komarudin, R., \& Noor, R. R. (2017). Analisis Perancangan Media Pembelajaran Animasi Interaktif Mengenal Bahasa Jepang. Jurnal Pilar Nusa Mandiri, 13(ISSN 1978 - 1946 \& E-ISSN 2527 - 6514), 12-20.

Madcoms. 2013. Mahir Dalam 7 Hari Adobe Photoshop CS6. Madiun: Andi Offset.

Mahardika, A., \& Destiana, H. (2014). Animasi Interaktif Pembelajaran Pengenalan Hewan Dan Alat Transportasi Untuk Siswa Taman Kanak - Kanak. Jurnal Pilar Nusa Mandiri, $\mathrm{X}(1)$.

Mulyani, A., \& Armanda, D. (2015). Perancangan animasi berkendara yang aman dan nyaman. Jurnal Techno Nusa Mandiri, XII(1), 41-48.

Munir. 2015. Multimedia Konsep \& Aplikasi Dalam Pendidikan. Bandung: Alfabeta.

Puspitorini, I. (2016). SNIPTEK 2016 RANCANGAN ANIMASI INTERAKTIF PENGENALAN ALAT-ALAT Seminar Nasional Ilmu Pengetahuan dan Teknologi Komputer Nusa Mandiri Seminar Nasional Ilmu Pengetahuan dan Teknologi Komputer Nusa Mandiri. SINPTEK, (ISBN: 978-60272850-3-3), 399-404.

Saryoko, A., \& Susilowati. (2018). Multimedia Interaktif Edukasi Limbah Sampah dan Cara Pengelolaannya Menjadi Barang Kerajinan Tangan. Perspekstiftif, XVI(p-ISSN: 14118637 e-ISSN: 2550-1178).

Sigalingging O, S. dan B. Y. (2016). Sistem Informasi E-Kepegawaian Pada PT. MannaPratama Santosa Jakarta. Information System For Educators And Professionals, 1(1), 55-66.

Sukamto, Rosa A, M.Shalahuddin. 2013. Rekayasa Perangkat Lunak Terstruktur dan Berorientasi Objek. Bandung: Informatika Bandung.

Supriyadi. (2018). Interaksi Objek Animasi SD Berbasis Multimedia. Jurnal Khatulistiwa Informatika, VI(p-ISSN:2339-1928\&eISSN:2579-633X), 64-72.

\section{PROFIL PENULIS}

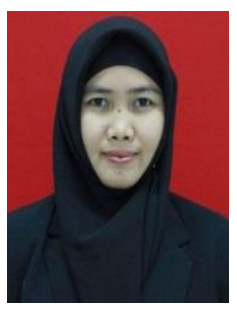

Narti, M.Kom. Tahun 2014 lulus pendidikan Program Strata Satu (S1) Program Studi Sistem Informasi Sekolah Tinggi Manajemen Informatika dan Komputer (STMIK) Nusa Mandiri Jakarta. Tahun 2016 lulus Program Strata Dua (S2) Pascasarjana STMIK Nusa Mandiri dengan konsentrasi bidang Manajemen Information System (MIS). Aktifitas sebagai dosen STMIK Nusa Mandiri Jakarta.

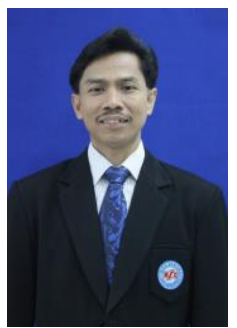

Sriyadi, M.Kom. Tahun 2005 lulus pendidikan Program Strata Satu (S1) Program Studi Sistem Informasi Sekolah Tinggi Manajemen Informatika dan Komputer (STMIK) Nusa Mandiri Jakarta. Tahun 2011 lulus Program Strata Dua (S2) Pascasarjana STMIK Nusa Mandiri dengan konsentrasi bidang Manajemen Information System (MIS). Aktifitas sebagai dosen Universitas Bina Sarana Informatika. 


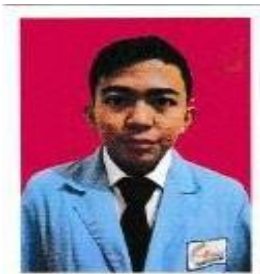

Darul Annas Septihan, S.Kom. Tahun 2014 lulus pendidikan Sekolah Menengah Atas Negeri 11 di Kabupaten Tangerang, Tahun 2018 lulus pendidikan program studi Sistem Informasi Sekolah Tinggi Manajemen Nusa Mandiri Jakarta. Informatika Dan Komputer

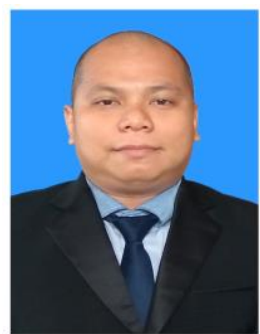

Mahmud Syarif, S.E, M.M. Tahun 2010 lulus pendidikan Program Strata Satu (S1) Program Studi Akuntansi pada Universitas Persada Indonesia YAI. Tahun 2015 lulus Program Strata Dua (S2) Universitas BSI Bandung program studi Manajemen.

Aktifitas sebagai dosen Universitas Bina Sarana Informatika. 